\title{
DOI: 10.7596/taksad.v8i3.2199
}

Citation: Khalabuzar, O., Kondratieva, O., Chykil, M., \& Nikishyna, T. (2019). Formation of Students' Logical Thinking within the Multicultural Educational Society. Journal of History Culture and Art Research, 8(3), 150-161. doi:http://dx.doi.org/10.7596/taksad.v8i3.2199

\section{Formation of Students' Logical Thinking within the Multicultural Educational Society}

\author{
Oksana Khalabuzar ${ }^{1}$, Olena Kondratieva², \\ Maria Chykil $^{3}$, Tetiana Nikishyna ${ }^{4}$
}

\begin{abstract}
The article focuses on the analysis of the aspects of training of future teachers within the modern multicultural society. The modern process of education is characterized by an interacting process of globalization. The multicultural orientation is reflected in the educational standards of teachers' preparation. These processes cause reform of the education system for Bachelors and Masters of pedagogical specialties. A modern future teacher should be able to create a dialogue with all the participants of the society and human intercultural relationships within the educational process. The article identifies pedagogical conditions for the effectiveness of the formation of students' culture of logical thinking. The solutions of the stated goal were provided by a set of methods: systemic interviewing, nonstandard tasks, and interactive educational technologies, oriented on the forming of logical skills, testing, questioning, statistical method. The authors of the article offer a number of recommendations for moreeffective ways of training future teachers. Special emphasize should be made on the formation of a positive motivational component which is oriented on the realization of personality's potential abilities and gives the opportunity to form and to develop logical thinking. The article contains the strategy of forming a positive attitude and positive motivational atmosphere within the educational process, the method of nonstandard educational work (case study which presents the way of formation multicultural thought, brainstorms, discussions, on-line conferences, mind-maps, etc). The methods of charting, through which students were able to discuss the term or the notion, analyzing positive and negative features, were used for the formation of a culture of logical thinking. Diagnostics of the quality level of students' logical skills by questioning to determine the level of formation of abilities to analyze, to compare, to determine the main idea, to generalize and to make correct conclusions. The strategy, oriented on the creation of a dynamic atmosphere, on the mobilization of the students' logical thinking is proposed.
\end{abstract}

Keywords: Multicultural educational society, Culture, Logical thinking skills, Training of future teachers.

\footnotetext{
${ }^{1}$ Berdyansk State Pedagogical University, the Faculty of Philology and Social Communications, Shmidta St., 4, Berdyansk town, Zaporozhye region, Ukraine, 71112. E-mail: oxa-khalabuzar@ukrl.net

${ }^{2}$ Berdyansk State Pedagogical University, the Faculty of Philology and Social Communications, Shmidta St., 4, Berdyansk town, Zaporozhye region, Ukraine, 71112. E-mail: kondratievaelena84@gmail.com

${ }^{3}$ Berdyansk State Pedagogical University, the Faculty of Philology and Social Communications, Shmidta St., 4, Berdyansk town, Zaporozhye region, Ukraine, 71112. E-mail: chikilmaria1504@gmail.com

${ }^{4}$ Berdyansk State Pedagogical University, the faculty of philology and social communications, Shmidta St., 4, Berdyansk town, Zaporozhye region, Ukraine, 71112. E-mail: tinikishyna@gmail.com
} 


\section{Introduction}

Increasing development of social paradigm within multicultural educational society demands the creation of effective ways of professional training of future teachers. Such teacher has to be able to analyze, to understand the complexity of the multicultural educational society, to solve various social problems, to think logically, to construct strong community and to teach young generations to state goals, to achieve them without conflicts, would be able to correspond with various aspects of innovative community's life.

The modern socio-cultural situation leads to the development of educational cooperation, interaction, and multicultural communication. Thus, the modern teacher within the multicultural society orients students on the formation of such professional qualities as: tolerance for opposing views, compromise of problems, and logical thinking. The present geo-cultural situation requires from the future specialist skills of creating a dialogue with all the participants of the educational society; skills of supporting human intercultural relationships with cultural representatives, countries, ethnos, and nations. In our opinion, all mentioned qualities and social requirements could be guaranteed with the help of the multicultural educational society, oriented on the formation of a culture of logical thinking. The forming the culture of logical thinking gives the individual an opportunity to reflect on his mind the objective reality, processes, objects, events, cases, objects and their originality, the ability to reflect the important connections and the relationships between them in the form of ideas, concepts and discussion (problems of scientific hypotheses, theories). In turn, the students must carefully learn the most important concepts of the essence of the conversation (dialogue), to understand the relationship between them, step by step and rapidly learn the skills of finding logical framework decisions (conclusion).

\section{Literature Review}

The reform of the education system of Ukraine within the global integration increases the requirements for the process of training the modern teacher, so the main components of the future teachers' professional preparation are multicultural competence (A. Antonova, V. Dorohova, N. Yashyn, A. Ahadulin, S. Belyaev, V. Bolharyna, A. Solodka), tolerance (Y. Dovhopolova, O. Hryva, M. Chepovetska, O. Kozlova, T. Varenko, R. Valytova, S. Ostrykova), logical skills (L. Vygotsky, P. Galperin, I. Lerner, N. Menchinskaya, I. Homenko), creativity (O. Dubaceniuk, S. Ovcharov, H. Batyshev, V. Bosenko, N. Hryshenko, H. Davydova, L. Zlotyna, P. Kramar, V. Mezhyev, B. Novykov), critical thinking (V. Bereza, V. Yahodnykova, O.Zahashev, V. Buryak), intercultural communication (N. Nikityna, V. Nechayeva, M. Soter, A. Lukanovska, O. Ihnatenko, F. Bacevitch, O. Kuchmiy, M. Safina, O. Shestel, N. Voronkova, M. Halycka, O. Tepla).

I. Kovalynska (2016) presents fundamental features of multicultural educational society as the orientation on human values of student's individuality, on the protection of rights on education, on providing free choice of educational ways for all students, on the development of readiness to cooperate within different cultural traditions, on the increasing of the creative potential of all participants of the educational processes.

According to L. Pet'ko (2017), the system of multicultural education is oriented on future specialists' personal development. The realization of the future teacher's training must be based on the cultural heritage within interrelation with other cultures and contrasts consideration caused by ethnos origin, nationality, social status, physical opportunities that have different features. 
$\mathrm{H}$. Lavreshyna (2000) mentions that the optimistic human conception is oriented on potential abilities and gives an opportunity to form and to develop logical thinking.

\section{Discussion}

In the conditions of transformation processes in the modern multicultural society mastering logical knowledge and skills, skillful use of them in practice contributes to the formation of selfconsciousness, the intellectual growth of the personality of the future teacher, which in subsequent practice will help the student understand the relationships of the phenomena of social life within the environment of the multicultural society. The characteristics of a modern teacher should include independence, flexibility, reflexivity, creativity, systemic, criticality, openness, which will allow to solve successfully both social and professional tasks, create favorable conditions for education and all the educational and harmonious development of students in accordance with the requirements of the present. Hence, as a goal, we determine the definition of skills that are necessary for the most effective process of forming of the personality of a future specialist within the multicultural educational society.

The fundamental functions of multicultural educational society are value-orientated function (formation system value-oriented contacts in context of interethnic relations); functions of multicultural self-orientation (gives opportunity to save individuality, ethno psychological and intercultural features); functions of social adaptation (preparation of civic features in context of cultural diversity); creative function (realization of creative personal potential through cognitive and social activity).

Multicultural component of future teacher professional pedagogical preparation is specified as the transference of multicultural knowledge, skills for cooperation with participants from other nations and tolerance activity in the context of cultural diversity; as the training skills of intercultural cooperation, as the gaining basic and professional knowledge. Within the multicultural society, we deal with the complex and diverse cultural world, with the equal existence of different cultures, with the tolerant cooperation, with the multicultural orientations and culture of communicating in a complicated society.

Scientists underline that the main objective of pedagogical educational establishments is the preparation of creative specialists with a high level of the culture of logical thinking. The modern pedagogue has to be oriented on the personal and professional self-education, he or she has to be ready for the professional activity on democratic and human basics, which is oriented on the development of educative, spiritual, and cultural needs in a multicultural society.

In our time of globalization, the transformation of multicultural society into higher forms is characterized by the democratic development of science and technology, when ideas are expressed and a whole range of difficult problems are solved. This stage is marked by the growing role of sciences in the versatile development of social life. So, the importance of students' logical thinking increases because of the high logical culture of the population of the country will contribute to the development and progress of the state and the world in general. As known, logic develops the intellectual abilities of a person, but, unfortunately, it is not a basic component of multicultural education either at school or during the training of students at higher education institutions. The ability of a person to think logically, that is consistently, precisely, and reasonably, is not given to a person at birth, it is formed in the process of learning. 
The educational multicultural society should teach students to argue their thoughts, participate in educational and cognitive discussions because without this form, scientific discoveries and innovations in the socio-economic activity of society are impossible. Future teachers must understand and feel the essence of socio-political and economic transformations. Science and technology are moving to a new stage of development when the significance of abstract thinking increases.

The logic that explores the structure of abstract thinking, its forms and laws may be useful to future specialists in various spheres of life. Cardinal changes cover an increasing number of layers of the multicultural population; require active social and political activity, the activity of logical thinking, etc. The process of education has always been and remains a social process, driven by the urgent needs of modern society. Training of professional personnel involves the educational process aimed at mastering the future teachers' ability to deal with the multicultural society, to think logically, to argue their thoughts (that is, to justify the truth of a certain judgment by guiding the true statements from which it logically flows), to deny false allegations, and so on (Lavreshyna, 2000).

In the context of the development of a democratic country and international cooperation, the role of intercultural collaboration is arising rapidly. The present development of multicultural society motivates all participants to be tolerant, logical, and responsible. Goals of national education, lead to the modern educational ways of the moral development and upbringing of responsible personality, able to interact within interpersonal, intercultural, intergovernmental, and universal spheres. The "person of culture with a high level of logical thinking" has to become the main result of the education within the multicultural educational society.

The pedagogical training of future teachers is the process that is influenced by complexes of dominant and subordinated actions, by the conscious and non-conscious actions. The student within the multicultural educational society is considered as an object of education but also as the person who needs certain motivation, instruction for the development of own personal logical skills. The student must obtain an active position in the educational process, so he should be intensively motivated for learning and getting logical knowledge, creating own educational process and developing the personal inner world (Lyannoi, 2016).

\section{Research Results}

The stated problems made us conduct experimental research. As the basis, we have chosen the students of the $1^{\text {st }}$ course, specialty "Computer Technologies" (Berdiansk State Pedagogical University). The experimental groups had representatives of different nationalities, including Bulgarians, Greeks, Russians, Ukrainians, Armenians, etc. During our experimental work, we tried to create a comfortable psychological condition of forming multicultural competence of future teacher within his or her active self-realization within the multicultural educational society. Personal selfrealization deals with the ability for realization, based on personal potential, using internal and external inner resources, continuing managing for development of personal abilities. Realization of personal values of existing in multicultural society arise cooperation, creativity, and activity in the world.

For effective work with our students, we proposed different surveys, training, case-studies, brain-storms, etc. In our opinion such surveys and questions are able to help students to understand 
their cultural identity and to form skills of effective cooperation with the representatives of different cultures:

1. How do you understand the concept of "multicultural competence"?

2. What does the term "multicultural society" mean to you?

3. How do you understand the concept of "multicultural education"?

4. How well do you know the cultural characteristics of your country?

5. How do you understand the concept of "intercultural dialogue"?

6. What do you think is the importance of multicultural education for future primary school teachers?

7. How do you understand the concept of "dialogue of cultures"?

8. How do you understand the following statement: "The priority principles of interaction of citizens must be cultural pluralism"?

9. Do you agree with the following statement: "The specificity of the current situation in the cultural world is the close convergence of all the peoples of the globe, which enables the dialogue of cultures and the presence of global problems, challenges of the existence of a society that can be solved with the help of representatives of all cultural environments"

10. What is the difference between the terms "multicultural competence" and "multicultural competence"?

11. How do you understand the concept of a "multicultural environment"?

After the work with the surveys, students had to exchange their answers with their partners and to discuss the results. This strategy helped to form a positive attitude and positive motivational atmosphere within the educational process.

For the personal development and for the self-analysis we proposed students to write the small essay according to the plan:

1. Your emotional attitude to the culture of other countries. (How do you react to the culture of other countries?)

2. Your attitude to representatives of other nationalities (Are you always tolerant to foreignspeaking citizens?)

3. Your reaction to the peculiarities of etiquette and everyday life (Is it always positive that you perceive the peculiarities of the rules of conduct in other countries)?

4. Your reaction to representatives of other religions (Do you normally refer to representatives of other religions)?

5. Your knowledge of the culture of other countries

6. Your knowledge of multicultural education.

7. Your ideas about cultural values.

8. Your independent cognitive activity in relation to other countries. 
9. Your views on the professional qualities of future teachers of an elementary school in the conditions of multicultural education in higher education.

10 What qualities would you like to obtain for the work in a multicultural educational society?

The written essays proved that some students underlined the lack of knowledge about the cultural heritage of other nationalities, about the cultural traditions of their own nationality. Besides, the essays were not logically structured, the answers were not clear. This made us to make the conclusion that the level of logical thinking has to be increased.

Considering the need of formation of high level of logical thinking of our students, we developed different non-standard lessons and tasks, oriented on the students' interconnection and interaction during the solving with the logical material (work with terms, concepts, arguments, ability to construct question and to answer them logically, comparison, analysis, etc.).

The conducted research proved that the formation of logical thinking within the multicultural society becomes more effective due to the non-standard forms of the educational work, including the case studies (education in simulated situations). The peculiarity of this technology is the students' ability to develop logical thinking at various stages:

- discussion forming the skills of rhetoric, ability to argue, to defend their own thoughts;

- "brainstorming", which prompts to analyze and synthesize the received information;

- "article to the newspaper", which makes in the abridged form a generalization of the casecase carried out and a conclusion-assessment.

All of the mentioned stages will be reflected in the further professional activity of the teacher within the multicultural educational society. The necessity of solving non-standard scientific and technological problems makes such qualities as efficiency and heuristic thinking, will, imagination, independence and courage of decisions, and purposefulness especially important. These qualities do not appear in the structure of the personality independently, they should be purposefully formed, therefore, there is a need to ensure such a construction of the educational process, which would require a permanent need for the application of the above-mentioned qualities, would give students the opportunity to develop their logical thinking within the multicultural educational society. In our opinion, the method of case study presents the way of formation of multicultural thought by analyzing examples that demonstrate wrong behavior.

\section{Case study 1}

A head of ILT department at university received a CV from a job applicant. The CV was written in much the same way as it is accepted in the USA emphasizing all possible (and not so possible) applicant's strong points - awards and competences, MA and Ph.D. degrees, etc. The candidate was invited to the interview and demonstrated confidence, willingness to introduce and implement new approaches, eagerness to "plunge into work" no matter how complicated it could be. He spoke at length about his former experience of working in the USA and offered to share it with his would-be colleagues. Nonetheless his application was rejected. Why?

A. The head of the department thought that the boastful and overconfident candidate was a competitor aiming at her position. 
B. The head of the department distrusted what was written in CV, formed negative impression of the candidate during the interview and relied on her intuition and experience.

C. The idea of having a male teacher in the female department wasn't very appealing.

1) What problem has been created for the international student?

2) What problem has been created for the American?

3) What cultural misunderstanding caused the problem?

4) How would you solve the problem if you were the student?

5) Is there something you might do to ease the problem if you were the American?

\section{Case study 2}

Wei Ping thought she had done very well on yesterday's history test. When the test was returned, she was surprised to find she had received only 40 percent. She had done the first section perfectly but had received no credit for the second part, which she had also completed. While the professor was beginning some new lecture material, she asked why she had received such a low grade.

The professor said, "Read my comments. I don't remember your situation without looking at the test". Wei Ping still didn't understand why she had received no credit for the second part. She had answered all the questions, and she felt the professor was not being fair. After class she again questioned the professor, who said, "My comments indicate you didn't follow directions. Instead of writing one-word answers, you were supposed to write a full paragraph for each question". "I'm sorry. I didn't understand the directions. May I take the test again?" "I'm sorry, Miss Liu, but the directions were clearly stated at the beginning of that section of the test", the professor explained. "I can't give you a second chance just because you're a foreign student"

1) What problem has been created for the international student?

2) What misunderstanding caused the problem?

3) How would you solve the problem if you were the student?

5) Is there something you might do to ease the problem if you were that student?

\section{Case study 3}

During a lunch in a cafe, a foreigner asks you about the features of Ukrainian cuisine. Can you give him a full answer to his question (in a foreign language) and talk about special dishes from his country (of course, if you know something about them)?

1) What problem has been created for the international student?

2) What problem has been created for the American?

3) What cultural misunderstanding caused the problem?

4) How would you solve the problem if you were the student?

5) Is there something you might do to ease the problem if you were the American?

With the help of the case-studies, students received a solid, positive motivation for learning activities through emotional and cognitive satisfaction during each stage of the game. As a result of a skillfully conducted discussion, students discovered not only new knowledge but also improved 
communicative skills. Future teachers receive and work with the information that promotes: mastering their knowledge and skills of interaction with others' nationalities and cultures; formation of the motivational sphere of the personality of the future teacher of a multicultural educational society; development of pedagogical abilities and necessary personality traits; revealing creative abilities; the ability to respond promptly to certain situations within the multicultural educational society, manage them, anticipate the course of further events; promotes the formation of a positive attitude towards a person-oriented approach in education and in the further professional activity within the multicultural educational society.

In our opinion, the ability to analyze the concepts, to determine their positive and negative qualities, helps to form the logical thinking of the future teachers. Thus we have proposed a chart, through which students were able to discuss the term or the notion, to analyze its positive and negative features.

The formation of positive motivation for the formation of own logical thinking as an indicator of the culture of logical thinking was also facilitated by the technology of working out concepts, which allowed to determine the level of formation of abilities to compare, to determine the main, to generalize, and to draw conclusions. Students were offered a cube with inscriptions-instructions, which they had to implement during the process of describing the concept's characteristics.

Also, we've proposed the strategy, oriented on the creation of a dynamic atmosphere, on the mobilization of the students' logical thinking. We've widely used the three-level interleaving method. According to this strategy, students were divided into groups of three. Students had to discuss the problem of religious and cultural conflicts and to suggest some variants of the solution. There were some roles: Celebrity, Politician, Journalist, Pedagogue, Doctor, Soldier, etc. Students had to ask, answer, and to write the answers on different questions and to change their roles according to the scheme every 10 minutes.

Scheme of the Game "the Interview"

\begin{tabular}{|c|c|c|c|c|c|}
\hline A & B & \multicolumn{2}{|l|}{ C } & \multicolumn{2}{|l|}{ B } \\
\hline $\begin{array}{c}\text { Takes } \\
\text { interview }\end{array}$ & $\begin{array}{c}\text { Gives } \\
\text { interview }\end{array}$ & $\begin{array}{c}\text { Takes } \\
\text { interview }\end{array}$ & $\begin{array}{c}\text { Gives } \\
\text { interview }\end{array}$ & $\begin{array}{c}\text { Takes } \\
\text { interview }\end{array}$ & $\begin{array}{c}\text { Gives } \\
\text { interview }\end{array}$ \\
\hline \multicolumn{2}{|r|}{ 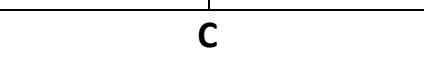 } & \multicolumn{2}{|c|}{ B } & A & Writes the interview \\
\hline
\end{tabular}

In order to improve the ability to ask questions, respecting culture and traditions of different nationalities, we propose to apply the questionnaire. The observations proved that such schemes allow students to rise from reconstructive to creative cognitive activity. The results were reflected in the expanded analysis of concepts, in the completeness of answers to questions, as drafting plans, notes, in the performance of individual tasks. The conducted studies indicate a positive dynamics in the formation of logical operations, the ability to identify causal relationships, the ability to compare objects, find them in common, in the ability to generalize and make correct conclusions. 
In our opinion, the formation of logical thinking within the multicultural educational society has to be interactive. Thus, we proposed students to work in groups of two, three, and five. They had to change social roles during various case studies, workshops, and training. They had to work with small texts, quotations, and to make certain tasks, which were oriented on the formation of logical thinking.

There is one example of the work with the educational cards, which contained the small samples from the different texts, describing the cultural traditions and customs:

1. Choose one of the proposed cards.

2. Try to predict the content of the card, tell your partner about your predictions.

3. Read the sample. Translate it.

4. Write at least 2 or 3 sentences, describing the educational material.

5. State the main idea and analyze it.

6. Write a short essay on the given topic, trying to describe the appropriate cultural traditions of your nationality.

7. Exchange the essays with your partner and discuss them.

8. Tell if you have been in such a situation. Explain your feelings and actions.

Such tasks helped to organize the interaction within the multicultural educational society, to make students to respect each other's cultural traditions and customs.

During the research we also developed a technology for working with short, meaningful texts, according to which students had to:

1. State the number for the sentences;

2. Select a sentence that is a chord from a relatively well-defined argument;

3. Select a sentence that is the reason for the argument;

4. Make "a tree of argumentation" using selected sentences.

Execution of the task contributed to the concentration of students on the main, stimulated self-control, strengthened the ability to establish causal relationships, that is, improved the ability to think critically in different social situations which were proposed students for the discussion.

\section{Situation 1}

During lunch in a cafe, a foreigner asks you about the features of Ukrainian cuisine. Give him a full answer to his question (in a foreign language) and talk about special dishes from his country (of course, if you know something about them)?

\section{Situation 2}

Imagine that you have entered the country of the language you are studying. You have been invited to a seminar on cultural studies. Would you agree to visit it, because you will need to tell about 
the cultural and historical events of your country and take part in the discussion on the cultural issues of this country?

\section{Situation 3}

You came to a foreign country. You live in a foreign family. In the evening, all family members gathered at the table. They ask about the cultural differences of your country. Will you be able to answer their questions and tell about some of your country's historical events? Will you ask the same thing about their country?

During the work with the proposed situations, students revealed the readiness to communicate with the representatives of different cultures, to respect their cultural heritage and to present own cultural traditions. The conditions of our experiment compelled students to express, analyze their thoughts, ask questions, to earn to formulate new provisions. To develop the ability to generalize it is necessary to develop observation, the ability to analyze, be able to allocate the main thing, to find substantial. To study generalization, we used the following paths: inductive - various subjects were displayed, their general and essential features were distinguished. Variation of signs has the purpose of distinguishing the essential features; inductive-deductive - on concrete examples the essence of concepts is explained. Subsequently, new versions of subjects are displayed and proposed to highlight common, common features and formulate certain concepts. possible while working with texts. Such a path involves induction, deduction, evaluation of concepts, improves the ability to generalize and provide substantiated conclusions.

During the formative experiment, students were asked to complete the Euler-Venn diagram. This task helps to better understand the relationship between concepts, which promotes a higher level of synthesis, is an effective means of memorizing and preserving the necessary information. In the first circle, you must enter options that are characteristic of one of the concepts, in the second one - his opponent. In the third one - the same way. On the square where three circles cross, it is necessary to insert common features for the concepts under consideration. Students acted in accordance with the plan:

1. Determine the signs of concepts.

2. Compare them.

3. Write the features that differentiate the notion of

4. Get a common feature

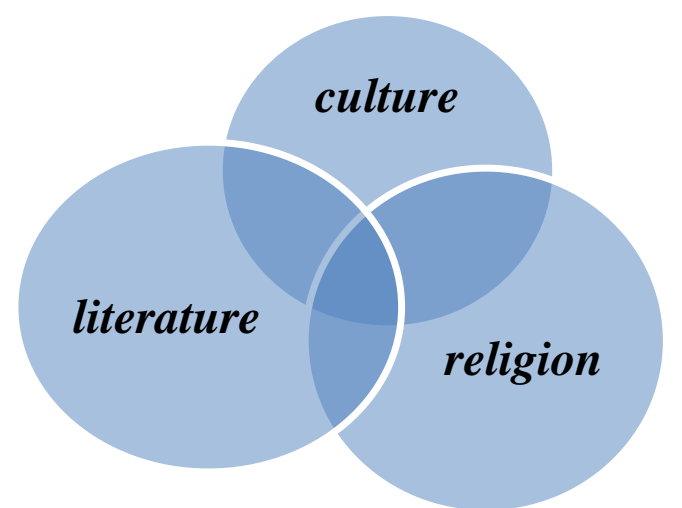

During the assignment, some students only painted the chart, typed their names to the ellipses, requested "Remind this word", "Prompt to synonym", "Check for errors". But the majority of 
students were positively adjusted to the task, thanked for non-standard tasks, performed them almost unmistakably, clearly formulated a common concept and explained their answers.

Students showed great interest during the task of assembling an associative chain when they were asked to write their own line of associations to the provided plaque. The task was carried out within 1-2 minutes on specially developed cards, which were of great importance for increasing the attention of students and had the purpose of mobilizing, activating the vocabulary of students and creative, logical thinking. The task was fulfilled briskly by all students

The conducted research proved that the main challenges of the future teacher's training deal with the pedagogical potential of multicultural society for the formation of the students' logical thinking. We must understand the cultural and linguistic variety of Ukrainian society, we must develop the respect and tolerance for intercultural interaction. During the forming experiment, one method of control was supplemented by several others, which allowed the objects to see the assessment, make it deeply motivated.

\section{Conclusion}

As a result, the principal specification of multicultural education makes us to use the potential of educational society and social environment for cultural flow and to consider all participants, to arise cognitive, cultural, educative needs of students and to develop the logical thinking of our students. The multicultural educational society of high educational establishments help the mentally completed atmosphere of personal interaction which provides paradigm, style, behavior and stimulates necessity of participation in national mental values and ideals.

As the conclusion we can determine that the process of modern educational training, which is oriented on the logical thinking of the future teacher within the multicultural society, could be effective in case of implementation of the process of experimental education, during which must be used nonstandard forms of work, the appropriate means, various methods and forms of control over the process of forming the students' logical thinking within the multicultural educational society.

Our further research will be devoted to the peculiarities of the formation of the students' logical thinking (within the multicultural society) with the help of modern computer technologies.

\section{References}

Antonova, O. (2015). Vplyv polykulturnoho seredovysha na rozvytok maybuthyh pedagogov. Vinytsa.

Dorohova, V. (2005). Polykulturnye aspekty pidhotovki vchytelya molodshyh klasiv. Cherkasy.

Dovhopolova, Y. (2005). Tolerantni vydnosiny u polikulturnomu seredovyshy. Lviv.

Homenko, I. (2004). Lohika: pidruchnik dlya navchalnyh zakladiv. Kyiv.

Hryva, O. (2004). Socialno-pedahohychna model formuvanya tolerantnosty. Zhytomir.

Ivanyi, I. (2016). Model formuvannya profesino-pedagogichnoi kulturi maibutnogo phahivtcya u protcesi profesyinoi pidgotovki. Nauk. Jurnal. Sumi.

Krilova, N. (2000). Kulturologya obrazovaniya. Novie tcennosti obrazovaniya. 
Lavreshyna, H. (2000). Formuvannia lohichnoi kultury u protsesi navchannia. Avtoref. dys. kand.. ped. nauk. Kryvyi Rih

Lyannoi, Y. (2016). Profesyina pidgotovka maibutnih magistriv z phizichnoi reabilitatcii u vishih navchalnih zakladah: teoretiko-metodichnyi aspect. [Monographiya]. Sumi

Pet'ko, L. (2017). Multicultural upbringing of students and the formation of professionally oriented foreign language teaching environment. Perspectives of research and development: Collection of scientific articles. SAUL Publishing Ltd, Dublin, Ireland

Savchenko, O. (2011). Kompetentnisny’j pidxid yak chy`nny’k yakosti profesijnoyi pidgotovky` majbutn`ogo vchy`telya. Donecz’k. Kashtan

Solodka, A. (2005). Polykulturne vyhovanya i osvita. Mykolayv.

Yashyn, N. (2014). Formuvanya tolerantnosty studentiv v umovah polikulturnoho seredovyshya. Nauk. Jurnal. Kuiv. 